\title{
UNDERGRADUATE STUDENTS' ATTITUDES TOWARD INDONESIAN LANGUAGE IN HIGHER EDUCATION
}

\author{
Nurulanningsih NURULANNINGSIH \\ Universitas Tridinanti, Indonesia \\ E-mail: nurullaningsih@univ-tridinanti.ac.id
}

Amirul MUKMININ

Universitas Jambi, Indonesia

E-mail: amirul.mukminin@unja.ac.id

Nurhayati NURHAYATI

Universitas Sriwijaya, Indonesia

E-mail: nurhayati@,fkip.unsri.ac.id

Marzul HIDAYAT

Universitas Jambi, Indonesia

E-mail: mhiday@unja.ac.id

Lenny MARZULINA

Universitas Islam Negeri Raden Fatah, Palembang, Indonesia

E-mail: lennymarzulina uin@,radenfatah.ac.id

Kasinyo HARTO

Universitas Islam Negeri Raden Fatah, Palembang, Indonesia E-mail: masyo_71@yahoo.com

Fridiyanto FRIDIYANTO

UIN Sulthan Thaha Saifuddin Jambi, Indonesia

E-mail: fridiyantofridiyanto@yahoo.com

Dian ERLINA

Universitas Islam Negeri Raden Fatah, Palembang, Indonesia

E-mail: dianerlina_uin@radenfatah.ac.id

Muhammad HOLANDYAH

Universitas Islam Negeri Raden Fatah, Palembang, Indonesia

E-mail: muhamadholandyah_uin@radenfatah.ac.id

ABSTRACT: This study aimed to examine students' attitudes toward Indonesian language from public and private universities in Indonesia. Additionally, this study examined what aspects are considered unfavorable or adverse from students' attitudes towards the Indonesian language. The online questionnaires with 30 statements were used to collect the data from 812 students from public universities and 705 students from private universities. The instrument's validity was carried out by 
two methods of testing, namely the content validity test and the testing. The data were analyzed by using descriptive statistics with Independent T-test sample test. The findings revealed that students' attitudes towards Indonesian both from state universities and private universities were both in a good category, and there was no difference in the results of the different test attitudes with a significance value of 0.970 . In terms of the aspects of loyalty and pride towards Indonesian, it was in a sufficient category. The findings also indicated that students' attitudes in public and private universities were categorized as sufficient. For this reason, lecturers who teach the Indonesian personality development course further foster students' awareness to be loyal and proud of the Indonesian language by prioritizing Indonesian in every academic activity. It is necessary to develop a sense of loyalty, pride, and awareness of norms towards the Indonesian language even higher.

KEYWORDS: attitudes, Indonesian language, formal instruction, undergraduate students, higher education, language policy, students' language awareness

\section{Introduction}

Language attitudes refer to mental and behavioural attitudes. Language attitudes can be observed by language behaviours/speech behaviours. Language attitude is a psychological event and is part of attitude in general (Kridalaksana, 2011; Aslinda \& Syafyahya, 2007; Suandi, 2014). The characteristics of a positive attitude towards a language include (1) language loyalty which encourages people who have the language to maintain their language and, if necessary, prevent other languages' influences, (2) language pride which encourages people who have the language to develop their language and use it as a symbol of identity and community unity, (3) awareness of the norm which encourages people to use their language carefully and politely; and it is a factor that has a tremendous influence on actions, namely the activity of using language. Mansyur (2018), in his study, found that positive language attitudes in higher education are not entirely positive for some students. This is because students tend to be more confident when they use foreign languages. Also, Mulyaningsih (2017) found that Indonesian is underestimated because Indonesian has been used as an everyday language. Additionally, Indonesian has been taught since elementary school, so it is not surprising that Indonesian is considered unnecessary to be studied in college.

Research on attitudes towards Indonesian was carried out by several other researchers, namely Alimin and Gesrianto (2017), Kustomo (2011), Wardani, Gosong, and Artawan (2013) and Wistari, Suandi, and Wendra (2015). Most of the findings of these studies revealed that students' attitudes towards Indonesian were positive. For example, Ahmad's study (2018) showed that loyalty to the Indonesian nation showed negative language attitudes and the indicators of pride in Indonesian showed a negative attitude, while the indicators of the tendency to use Indonesian showed a positive attitude. Additionally, Mulyaningsih (2017) found that the attitude of college students towards Indonesian language was categorized into a good level. Also, Wardani, Gosong, and Artawan (2013) and Wistari, Suandi, and Wendra (2015) found that in general, students' attitudes were in a positive category. Moreover, Alimin (2017) found that students had positive attitudes towards the three aspects (loyalty pride, and awareness) of language attitudes. Although, there were several previous studies that examined students' attitudes towards Indonesian, they only focused on one or two universities. This current study aimed to examine students' attitudes towards Indonesian language from two public and twelve private universities in Indonesia. Additionally, this study examined what aspects are considered unfavorable or adverse from students' attitudes towards the Indonesian language.

\section{Methods}

This study used a quantitative approach with a survey research design. We examined quantitatively (numbers) trends, behaviors, or opinions of a population by examining this population sample. We attempted to generalize or make claims about that population, particularly students' attitudes toward Indonesian language from public and private universities in Indonesia. This study was in the form of cross-sectional, where we only observed the phenomenon at a certain point in time or a momentary time. This study was conducted at 14 universities consisting of 2 public universities and 12 private universities in Palembang City, Indonesia. The state universities are Sriwijaya University and Raden Fattah State Islamic University, while private universities are Muhammadiyah Palembang University, Bina Darma University, IBA Palembang University, Tridinanti Palembang University, Palembang PGRI University, Kader Bangsa University, Palembang University, Syakyakirti University, University Musi Charitas, Taman Siswa University, Indo Global Mandiri University, and University of South Sumatra. The participants who were involved in this study were 1517 students consisting of 812 students from state universities and 705 students from private universities. The sampling technique used 
was random sampling. This sampling technique provides equal opportunities for each member of the population to be selected as a sample (Creswell, 2010).

The data collection technique used in this study was a questionnaire. The questionnaire used a Likert scale. Data were collected by a Google form with 30 statements. The instrument's validity was carried out by two methods of testing, namely the content validity test and the testing. The first way is the content validity. This process shows to what extent the questionnaire is made to demonstrate a relevance and representation to the realm of the task which is being measured. The second way is questionnaire trials. The trial was done with the students outside of the participants (samples) used in the research. The testing technique used was the think-aloud technique. Johnson and Christensen (2008) revealed that this testing technique was carried out by asking the trial participants to express their thoughts and perceptions on the questionnaire. We wrote down everything about the opinions that the participants gave. Using this technique, it could help us determine whether the trial participants had the same interpretation of each item which is stated in the questionnaire. The attitude data that had been obtained was calculated by using the Independent Sample Test T-test. The T-test is a statistical test that can test the difference or similarity of two conditions/treatments or two different groups with the principle of comparison of the mean of the two groups/treatments (Subana, Rahadi, \& Sudrajat, 2015). This difference test found no difference in students' attitudes at public and private universities towards Indonesian. For categorizing students' attitudes towards Indonesian, it was done by first looking for the average score on the three aspects of language, namely elements of loyalty, pride, and awareness towards the Indonesian language norms. After the average value of the three parts had been obtained and each aspect's categorization had been received, the next step was to determine the overall average of value (the combination of the three factors - loyalty, pride, and awareness) after the average value had been obtained and then we calculated the general language attitude category.

\section{Findings and Discussion}

\subsection{The Attitude of Students from State Universities towards the Indonesian Language}

The aspect of loyalty to the Indonesian language consists of 6 positive statements and three negative statements. The positive statements cover items of 9 (the name of the building, streets or other public places should not be written in English), 11 (it demands me that it is important to preserve the Indonesian language), 18 (I am sure that Indonesian will survive in this modern era), 20 (I will not use foreign languages in my scientific writing), 21 (people should minimize the use of foreign languages because it will damage the Indonesian language), and 27 (I like if students or lecturers are responsible for preserving the Indonesian language by using it in every academic activity). The average score obtained was 3.62, 4.83, 4.49, 3.12, 3.26, and 4.47. Meanwhile, the statements which include items of 4 (if you can speak a foreign language, it looks cooler), 5 (I am proud if I am able to communicate in English), and 24 (I think it is fine if we use a foreign language in our country) obtained average values, namely $2.55,1.80$, and 2.21 . Based on each statement's average result on the aspect of loyalty to Indonesian, the overall average weight for this aspect was 30.35 . There were five positive statements and six negative statements in the aspect of pride in the Indonesian language. Positive statement items include 14 (If there is a formal forum, both national and international ones, I will continue using Indonesian), 16 (I am proud if tourists can speak Indonesian), 23 (I am very happy that Indonesian is learned abroad), 26 (I prioritize to use terms in Indonesian), and 29 (I will always use Indonesian). The average values obtained were $3.76,4.52,4.62,3.97$, and 3.86. Negative statements were 1 (In my opinion, students do not have to use Indonesian in every teaching and learning activity on campus), 2 (Talking with friends and lecturers when discussing in front of the class does not have to use Indonesian), 3 (I feel embarrassed when I see other friends using Indonesian), 6 (It is normal to see someone who can speak Indonesian properly and correctly), 7 (I laugh at my classmate when he speaks Indonesian, especially if he says it wrong), 12 (I don't like to use Indonesian) which obtained an average score of 3.49, 3.64, 3.87, 2.74, 4.03, and 4.41. Based on each statement's average result on the aspect of pride in the Indonesian language, the overall average value for this aspect was 42.91 .

The aspect of awareness of language norms consists of 8 positive statements and two negative statements. Positive statement items were 8 (I do not like seeing other people using Indonesian carelessly), 13 (I always do editing before collecting assignments given by lecturers), 15 (I like 
correcting my friends if they make a mistake in using Indonesian), 17 (I like to listen or pay attention to the lecturer explaining the material about the Indonesian language), 19 (I like increasing my knowledge of Indonesian) 22 (I feel embarrassed if I cannot write a paper or thesis properly and correctly in Indonesian), 25 (If there is a term that I do not know, I will find it out in the Indonesian dictionary or ask a lecturer directly), 28 (I adjust my speech by seeing who I am talking to) with the average value of 3.96, 4.34, 4.00, 4.30, 4.29, 4.52, 4.34, and 4.48. Negative statements were 10 (It does not matter if there are mistakes in writing assignments such as essays, papers, or other scientific works, the important thing is that the assignments have been collected) and 30 (I do not want to learn Indonesian more deeply) with the mean values of 3.79 and 3.99. Based on each statement's average result on the aspect of awareness of Indonesian language norms, the overall average score for this aspect was 42.01. After obtaining the average results of the three aspects of students' attitudes from state universities towards Indonesian, the overall average was 115.26. The average score for each aspect and as a whole had been obtained. The next step was to do the categorization to see students' attitudes from state universities towards Indonesian. The following is a categorization table that we determined based on the calculations that had been done.

Table 1. Categories of attitudes of students from state universities towards Indonesian

\begin{tabular}{|l|c|c|}
\hline Aspects & Average Value & Categories \\
\hline Loyalty & 30.35 & Enough \\
\hline Pride & 42.91 & Enough \\
\hline Awareness & 42.01 & Enough \\
\hline Overall attitude & 115.26 & Enough \\
\hline
\end{tabular}

Based on the description in the table 1, the loyalty aspects of the Indonesian language for the state university students were enough and the average value was 30.35 . The pride aspects of the Indonesian language for the state university students were also enough and the average value was 42.91 . Furthermore, the awareness aspects for the Indonesian language norms for the state university students were also enough with the average value of 42.01. The overall attitude of the state universities students was in the enough category with the average value of 115.26 from the three aspects of attitude towards the Indonesian language.

3.2. The Attitude of Students from Private Universities towards the Indonesian Language

The aspect of loyalty to the Indonesian language consists of 6 positive statements and three negative statements. Positive statement items obtained an average score of 3.84, 4.77, 4.61, 3.50, 3.54, and 4.48. The negative statement items had the average value of 2.63,1.86, and 2.28. Based on each statement's average result on the aspect of loyalty to Indonesian, the overall score in that aspect was 31.52. There were five positive statements and six negative statements in the aspect of pride in the Indonesian Language. Positive statement items had the average values of 4.07, 4.55, 4.61, 4.11, and 4.05. Negative statement items obtained average values of 3.29, 3.41, 3.56, 2.65, 3.73, and 4.23. Based on each statement's average result on the aspect of pride in the Indonesian language, the overall average score for this aspect was 42.24. The aspect of awareness of language norms consists of 8 positive statements and two negative statements. Positive statement items were obtained an average value of 4.00, 4.16, 4.06, 4.34, 4.38, 4.47, 4.37, and 4.40. Negative statement items were obtained an average value of 3.52 and 3.82. Based on each statement's average result on the aspect of pride in the Indonesian language, the average score for all these aspects was 41.52. After obtaining the average results of the three aspects of student attitudes from private universities towards Indonesian, the overall average was 115.28 .

Table 2. Categories of attitudes of students from private universities towards Indonesian

\begin{tabular}{|l|c|c|}
\hline Aspects & average value & Categories \\
\hline Loyalty & 31.52 & Enough \\
\hline Pride & 42.24 & Enough \\
\hline Awareness & 41.52 & Enough \\
\hline Overall attitude & 115.28 & Enough \\
\hline
\end{tabular}


Based on table 2, it can be explained that students from private universities fell into enough categories for the loyalty to the Indonesian language aspects. For the aspects of pride in the Indonesian language and awareness of the Indonesian language norms, students from private universities were also in a sufficient number of categories. Based on the average score for each aspect of attitudes towards Indonesian, it was found that students' overall attitude from private universities was categorized as sufficient, with an average score of 115.28.

Table 3. The comparison of students' attitudes from public and private universities towards Indonesian

\begin{tabular}{|c|c|c|c|c|c|}
\hline \multicolumn{3}{|c|}{$\begin{array}{l}\text { The Attitudes of public universities } \\
\text { students }\end{array}$} & \multicolumn{3}{|c|}{ The Attitudes of private universities students } \\
\hline Indicator & $\begin{array}{l}\text { Average } \\
\text { value }\end{array}$ & Category & Indicator & Average Value & Category \\
\hline Loyalty & 30.35 & Enough & Loyalty & 31.52 & Enough \\
\hline Pride & 42.91 & Enough & Pride & 42.24 & Enough \\
\hline $\begin{array}{l}\text { Awarene } \\
\text { ss }\end{array}$ & 42.01 & Enough & Awareness & 41.52 & Enough \\
\hline Total & 115.26 & Enough & Total & 115.28 & Enough \\
\hline
\end{tabular}

Table 3 shows the comparison of the average score for students' attitudes from public universities and private universities towards Indonesian. The three aspects, namely language loyalty, language pride, and awareness of language norms, are categorized as sufficient. Overall, the average score of students from state universities obtained an average score of 115.26. Students from private universities had an average score of 115.28 , with an average difference of 0.02 between the two.

\subsection{Testing the Differences in Attitudes of Students from State and Private Universities towards Indonesian}

The mean score and attitude categorization of the two groups of students had been taken. The next step was to prove whether the two groups have different attitudes, then the test was carried out by using the Independent Sample Test. The test criteria in this study were carried out by looking at the probability number. If the probability value (sig) 0.05 , then Ho was accepted and if the probability number value (sig) 0.05 , then Ho was rejected. The following is presented a test table by using the Independent Sample T-test.

Table 4. T-test of students' attitudes from state and private universities towards Indonesian

\begin{tabular}{|c|c|c|c|c|c|c|c|c|}
\hline \multicolumn{9}{|c|}{ Independent Samples Test } \\
\hline & & \multicolumn{2}{|c|}{$\begin{array}{c}\text { Levene's Test for } \\
\text { Equality of } \\
\text { Variances }\end{array}$} & \multicolumn{5}{|c|}{ t-test for Equality of Means } \\
\hline & & $\mathrm{F}$ & Sig. & $\mathrm{t}$ & $\mathrm{df}$ & $\begin{array}{c}\text { Sig. } \\
(2 \text { tailed })\end{array}$ & $\begin{array}{c}\text { Mean } \\
\text { Difference }\end{array}$ & $\begin{array}{l}\text { Std. Error } \\
\text { Difference }\end{array}$ \\
\hline \multirow{2}{*}{\begin{tabular}{|l} 
Students' \\
attitudes \\
towards \\
Indonesian
\end{tabular}} & $\begin{array}{l}\text { Equal } \\
\text { variances } \\
\text { assumed }\end{array}$ & 2.569 & .109 & -.038 & 1515 & .970 & -.017 & .447 \\
\hline & \begin{tabular}{|l|} 
Equal \\
variances \\
not assumed
\end{tabular} & & & -.038 & $\begin{array}{r}1445 . \\
315\end{array}$ & .970 & -.017 & .450 \\
\hline
\end{tabular}

Based on the Independent Sample Test in Table 4, it can be seen that the significance value was 0.109 . This value is more significant than 0.05 , so it can be said that there is no difference in the variance of attitude data between students from state universities and students from private universities towards Indonesian. It can be said that the data were homogeneous. For this reason, we used data in the equal variances assumed path. Based on the data on the equal variances assumed, it was found that the twotailed significance value was 0.970 , and the value was more significant than 0.05 . Thus, this proved that there was no difference in attitudes between students from state universities and students from 
private universities towards Indonesian, so that the research hypothesis (Ha) was rejected.

\section{Discussion}

This study aimed to examine students' attitudes toward Indonesian language from public and private universities in Indonesia. The results showed those students' attitudes from the state universities and private universities were in a good category. In terms of loyalty aspect in Indonesian, the statement items given were nine statements consisting of 6 positive statements and three negative statements. For negative statement items, students from both state and private universities had the same average score, namely in the poor, very unfavorable, and unfavorable categories. Statement number 4 reads, "If you can speak a foreign language it looks cooler." Statement number 5 reads, "I am proud if I speak English," and statement number 24 reads, "I think it is okay if we use a foreign language in our country." These three statements are all related to foreign languages. Speaking a foreign language is cooler, being proud to speak a foreign language, and it is okay for a foreign language to be used in Indonesia. These facts are not in line with the theory put forward by Garvin and Mathiot (1968) on a loyal attitude to illustrated language if the user maintains the language of his country and, if necessary, prevents foreign influences. Like the aspect of loyalty, the aspect of pride in the Indonesian language, negative statement item number 6, students' answers from both public and private universities had the same average score, namely in the sufficient category. Statement number 6 reads, "It is normal to see someone can speak Indonesian properly and correctly." In this statement, it is seen that there is no sense of pride in someone who masters the Indonesian language well. According to students, it is an ordinary thing. The extraordinary thing is if you master a foreign language. This is not in line with the theory put forward by Garvin and Mathiot (1968) on a proud attitude towards illustrated language if users are proud of their language and are always encouraged using and developing their language.

In contrast to the two aspects above, in the aspect of awareness of the Indonesian language norms, all the average scores obtained by students from both public and private universities were in a good category. This means that students' attitude is in line with the theory of awareness of norms towards language proposed by Garvin dan Mathiot (1968). This attitude of understanding language norms carefully uses linguistic norms and is polite in its use. The results of the above research are in line with the research by Mansyur (2018). According to him, positive language attitudes in higher education are not fully positive for some students. This is because students tend to be more confident when they use foreign languages. Following Mulyaningsih's statement (2017), Indonesian is underestimated because Indonesian has been used as an everyday language. Indonesian has been taught since elementary school, so it is not surprising that Indonesian is considered unnecessary to be studied in tertiary institutions. Mulyaningsih added the number of people who like or learn foreign languages so that there are fewer Indonesian users, especially among students. According to him, this phenomenon arises supported by the assumption that an intelligent person is fluent in foreign languages. Mansyur (2016) found in his research that learning Indonesian in higher education was sometimes underestimated. This assumption arises because Indonesian is already used as an everyday language in interactions and has also been taught since elementary school.

In general, the value obtained by students' attitudes from state universities and private universities towards Indonesian was in a good category. It can be said that it is moderate, or it can also be categorized as a positive attitude. Thus, this study is in line with the results of previous studies, which were categorized as positive. Research on attitudes towards Indonesian was carried out by several researchers, namely Ahmad (2018), Kustomo (2011), Gesrianto (2017), Wardani, Gosong, \& Artawan (2013), Wistari, Suandi \& Wendra (2015) and Zuriyah (2015). The results obtained from these studies are in the positive category of attitudes towards Indonesian.

\section{Conclusions}

Students' attitudes toward Indonesian language from public and private universities in Indonesia were in a good category. Moreover, based on the results, the aspects of loyalty and pride towards Indonesian were categorized as sufficient, but there were items categorized as unfavorable. It recommends that other researchers may carry out further research to examine why students' attitudes towards the Indonesian language are categorized as sufficient with a broader sample size to maximize the results. For this reason, the South Sumatra Language Center is directly involved in coaching and developing the formation of positive attitudes towards the Indonesian language. Our findings also indicated that students' attitudes in public and private universities were categorized as sufficient. 
Therefore, lecturers who teach the Indonesian personality development course further foster student awareness to be loyal and proud of the Indonesian language by prioritizing Indonesian in every academic activity.

\section{REFERENCES:}

Ahmad, D. E. (2018).

Alimin, A. A, Hariyadi, \& Safrihady. (2017).

Aslinda \& Syafyahya, L. (2007).

Garvin, P. L., \& Mathiot M. (1968).

Gesrianto. J. (2017).

Johnson, B., \& Christensen, L. B. (2008).

Kridalaksana, H. (2011).

Kustomo. H. (2011).

Mansyur, U. (2018).

Mulyaningsih, I. (2017).

Rokhman, F. (2013).

Suandi, I. N. (2014).

Subana, Rahadi, M., \&

Sudrajat. (2015).

Wardani, K. D. K. A., Gosong, M., \& Artawan, G. (2013).

Wistari, N. W., Suandi, I. N., \& Wendra, I. W. (2015).
Sikap bahasa mahasiswa program studi pendidikan dasar pascasarjana universitas negeri makassar terhadap bahasa Indonesia [The attitude of the students of the Makassar state university postgraduate basic education study program towards Indonesian]. Makassar: Seminar Nasional Dies Natalis UNM Ke-57.

Sikap bahasa mahasiswa program studi pendidikan bahasa Inggris terhadap bahasa Indonesia [The attitude of the language of the students of the English education study program towards the Indonesian language]. // Jurnal Pendidikan Bahasa dan Sastra Indonesia, 2(1), 36-40.

Pengantar Sosiolinguistik [Introduction to Sociolinguistics]. Bandung: Refika Aditama.

The Urbanization of the Guarani language: A problem in language and culture. New York: State University of New York.

Analisis sikap bahasa dan motivasi belajar bahasa Indonesia siswa kelas XI SMA bosowa international school [Analysis of language attitudes and motivation to learn Indonesian for class XI students of bosowa international school]. // Jurnal Nalar Pendidikan, 5(1), 64-73.

Educational research: Quantitative, qualitative, and mixed approaches. Boston: SAGE Publications, Inc.

Kamus linguistic [Linguistic Dictionary]. Jakarta: Gramedia Pustaka Utama. Fenomena sikap berbahasa di Indonesia [The phenomenon of language attitude in Indonesia].// AL HIKMAH, 1(1), 82-91.

Sikap bahasa dan pembelajaran bahasa Indonesia di perguruan tinggi [Attitudes of indonesian language and learning in higher education]. Presented at the International Conference of Asosiasi Linguistik Terapan Indonesia (ICon ALTI) Universitas Muslim Indonesia, 11 Juli 2018.

Sikap mahasiswa terhadap bahasa Indonesia [Student attitudes toward Indonesian language]. // Journal Indonesian Language Education and Literature (ILEAL), 3(1), 79-87.

Sosiolinguistik suatu pendekatan pembelajaran bahasa dalam masyarakat multikultural [Sociolinguistics is an approach to language learning in multicultural societies]. Yogyakarta: Graha Ilmu.

Sosiolinguistik [Sociolinguistics]. Yogyakarta: Graha Ilmu.

Statistik pendidikan [Education statistics]. Bandung: Pustaka Setia.

Sikap bahasa siswa terhadap bahasa Indonesia: Studi kasus di sma negeri 1 singaraja [Students' language attitudes toward Indonesian: A case study at singaraja 1 public high school]. // Jurnal Pendidikan dan Pembelajaran Bahasa Indonesia, 2(1), 1-10.

Sikap bahasa siswa program cambridge dyatmika school terhadap bahasa Indonesia [The language attitude of cambridge dyatmika school students towards the Indonesian language]. // Jurnal Pendidikan Bahasa Dan Sastra Indonesia Undiksha, 3(1), 1-13. 